\title{
Composition of essential oils from three Ocimum species obtained by steam and microwave distillation and supercritical $\mathrm{CO}_{2}$ extraction
}

\author{
Maria Goretti de Vasconcelos Silva,, ${ }^{\text {a,b,c*}}$ Francisco José de Abreu Matos, ${ }^{\mathrm{c}}$ Paulo Roberto \\ Oliveira Lopes, ${ }^{b, c}$ Fábio Oliveira Silva, ${ }^{b, c}$ and Márcio Tavares Holanda ${ }^{\text {b,c }}$ \\ ${ }^{a}$ Departamento de Química Analítica e Fisico-Química ${ }^{\mathrm{b}}$ Departamento de Química Orgânica e \\ Inorgânica, Centro de Ciências, ${ }^{c}$ Laboratório de Produtos Naturais, Universidade Federal do \\ Ceará, CEP 60.021-970, Fortaleza-Ce, Brazil \\ E-mail: $\underline{\text { mgvsilva@ufc.br }}$
}

\section{Dedicated to Professor Otto Richard Gottlieb on the occasion of his $85^{\text {th }}$ birthday}

(received 11 Dec 04; accepted 31 July 04; published on the web 02 Aug 04)

\begin{abstract}
Essential oils (EO) from leaves of Ocimum gratissimum L., Ocimum micranthum Willd. and Ocimum selloi Benth. obtained by steam distillation (SD), microwave oven distillation (MO) and supercritical extraction with $\mathrm{CO}_{2}$ (SC) showed different composition by GC/MS analysis. The main components in the three essential oils were the same but in different relative amounts. The oil from O. gratissimum obtained by SD presented eugenol (54.0\%) and 1,8-cineole $(21.6 \%)$ as main components, by MO eugenol (34.6\%) and 1,8-cineole (22.6\%), and by SC eugenol (73.1\%) and 1,8-cineole (5.6\%). The essential oil from O. micranthum obtained by SD showed mainly eugenol (64.8\%), (E)- $\beta$-caryophyllene $(14.3 \%)$ and bicyclogermacrene $(8.1 \%)$; by MO eugenol (30.6\%), trans- $\beta$-caryophyllene (19.8\%) and elemicin (19.0), and the oil obtained by SC presented eugenol (56.7\%), elemicin (16.0\%) and trans- $\beta$-caryophyllene (4.0\%). Essential oil of $O$. selloi obtained by SD presented anethole (64.6\%) and linalool (20.6\%); by MO anethole $(67.4 \%)$ and linalool $(20.9 \%)$ and by SC anethole $(31.9 \%)$ and linalool $(23.2 \%)$ as main constituents. The type and quantitative variations of the chemical components of the analyzed oils in relation to the extraction methods were greater for O. micranthum.
\end{abstract}

Keywords: Ocimum gratissimum, Ocimum micranthum, Ocimum selloi, eugenol, essential oil

\section{Introduction}

The specialized literature has registered since many years the yields and chemical composition of several essential oils obtained by steam distillation, hydrodistillation and, more recently, by supercritical liquids extraction. 
According to the literature there are two chemical types of O. gratissimum L. in function of the main compounds in the essential oils from their leaves, the thymol type and the eugenol type. The second is common in home gardens of Northeastern Brazil. ${ }^{1}$

Previous studies on volatile oils from leaves of O. micranthum Willd. reported the occurrence of three chemotypes. The Indian chemotype which contain mainly eugenol, 1,8cineole, $\beta$-caryophyllene and $\gamma$-elemene ${ }^{2}$, the North-Brazilian chemotype from plants growing in Amazonian region which produces $\beta$-elemene, $\beta$-caryophyllene and isoeugenol as main components $^{3}$ and the NE-Brazilian chemotype, growing under low humidity climate and high solar light incidence, produces oil with eugenol, $\beta$-caryophyllene and elemicin as main components. ${ }^{4}$ A biological assay of the O. micranthum NE-Brazilian chemotype oil showed analgesic activities ${ }^{5}$ and the dichloromethane and methanol extracts obtained from this plant showed anticonvulsant, antispasmodic ${ }^{6}$ and antifungal activities. ${ }^{7}$

The essential oil of $O$. selloi leaves from Southeastern Brazil presented also two chemotypes: the estragole - methyl eugenol chemotype ${ }^{8}$ and anethole - estragole chemotype. ${ }^{9}$ These oils presented anti-diarrheic, anti-inflammatory and antispasmodic activities.

In view to detect the influence of different processes of extraction on the chemical constitution of these oils, leaves of Ocimum gratissimum L., Ocimum micranthum Willd. and Ocimum selloi Benth., growing under same conditions, were submitted to extraction by the following three process: conventional steam distillation, microwave distillation and supercritical $\mathrm{CO}_{2}$ extraction.

\section{Results and Discussion}

The analytical results are shown in Tables 1, 2 and 3 where the components are listed in order of elution on a DB-5 column. The essential oils of $O$. gratissimum show eugenol and 1,8-cineole as major constituents of leaves extracted by the three processes (Table 1), although the presence of $\alpha$-selinene, $\beta$-selinene, $\gamma$-muurolene, $\alpha$-humulene and (E)- $\beta$-caryophyllene have been observed in all samples studied but in lesser relative amounts. It was observed also a significant increase in the relative proportion of eugenol contents and a reduction in the amount of 1,8-cineole in the case of SC extraction.

The oils from $O$. micranthum showed larger variability, only three compounds were common in the studied samples: eugenol, (E)- $\beta$-Caryophyllene and elemicin. Eugenol was found in the three oils of $O$. micranthum (Table 2), but elemicin was detected in higher yield when the leaves were extracted by $\mathrm{SC}$ and $\mathrm{MO}$ methods.

The essential oils from leaves of $O$. selloi obtained by the three methods showed in common five constituents: 1,8-cineole, linalool, camphor, 4-terpineole, anethole and $\alpha$-(E)-bergamotene (Table 3). Anethole and linalool were found to be the major constituents in all methods, however by using SC the relative concentration of anethole decreased while epi-alpha-cadinol was detected in higher level. 
Table 1. Chemical composition of Ocimum gratissimum leaf essential oil

\begin{tabular}{ccccc}
\hline Constituents & KI & $\begin{array}{c}\text { SD } \\
\text { Yield \% }\end{array}$ & $\begin{array}{c}\text { MO } \\
\text { Yield \% }\end{array}$ & $\begin{array}{c}\text { SC } \\
\text { Yield \% }\end{array}$ \\
\hline$\alpha$-Pinene & 939 & 0.7 & - & - \\
$\beta$-Pinene & 965 & 2.6 & - & - \\
1,8-Cineole & 1004 & 21.6 & 22.6 & 5.6 \\
(Z)-Ocimene & 1021 & 4.1 & 1.7 & - \\
$\alpha$-Terpineole & 1189 & 0.7 & 1.6 & - \\
Eugenol & 1364 & 54.0 & 34.6 & 73.1 \\
(E)- $\beta$-Caryophyllene & 1422 & 5.3 & 10.5 & 5.6 \\
$\alpha$-Humulene & 1455 & 0.8 & 1.6 & 0.8 \\
$\gamma$-Muurolene & 1479 & 2.3 & 4.7 & 1.6 \\
$\beta$-Selinene & 1482 & 5.5 & 15.3 & 7.7 \\
$\alpha-$-Selinene & 1498 & 2.6 & 6.1 & 2.4 \\
\hline
\end{tabular}

$\mathrm{SD}=$ Steam distillation

$\mathrm{MO}=$ Hydrodistillation using microwave oven.

$\mathrm{SC}=$ Supercritical $\mathrm{CO}_{2}$ extraction .

Table 2. Chemical composition of Ocimum micranthum leaf essential oil

\begin{tabular}{ccccc}
\hline Constituents & KI. & $\begin{array}{c}\text { SD } \\
\text { Yield \% }\end{array}$ & $\begin{array}{c}\text { MO } \\
\text { Yield \% }\end{array}$ & $\begin{array}{c}\text { SC } \\
\text { Yield \% }\end{array}$ \\
\hline 1,8-Cineole & 1004 & 1.5 & 1.9 & - \\
Linalool & 1081 & 0.7 & 0.8 & - \\
Eugenol & 1364 & 64.8 & 30.6 & 56.7 \\
$\beta$-Elemene & 1389 & & - & 3.2 \\
Methyl-Eugenol & 1392 & & - & 4.4 \\
$($ E)- $\beta$-Caryophyllene & 1415 & 14.3 & 19.8 & 4.0 \\
$\alpha$-Humulene & 1445 & 2.3 & 3.3 & - \\
Allo-aromadendrene & 1452 & 0.7 & 0.7 & - \\
$\beta$-Selinene & 1477 & 1.5 & 2.2 & - \\
Bicyclogermacrene & 1486 & 8.1 & 12.5 & 3.5 \\
Germacrene A & 1503 & 2.0 & 4.6 & - \\
Eremofilene & 1512 & 1.1 & 1.9 & - \\
Elemicin & 1529 & 2.0 & 19.0 & 16.0 \\
\hline SD $=$ Steam distillation. \\
$\mathrm{MO}=$ Hydrodistillation using microwave oven. \\
$\mathrm{SC}=$ Supercritical $\mathrm{CO}_{2}$ extraction.
\end{tabular}


Table 3. Chemical composition of Ocimum selloi leaf essential oil

\begin{tabular}{ccccc}
\hline Constituents & KI & $\begin{array}{c}\text { SD } \\
\text { Yield \% }\end{array}$ & $\begin{array}{c}\text { MO } \\
\text { Yield \% }\end{array}$ & $\begin{array}{c}\text { SC } \\
\text { Yield \% }\end{array}$ \\
\hline 1,8-cineole & 1031 & 7.4 & 1.2 & - \\
Linalool & 1097 & 20.6 & 20.9 & 23.2 \\
Camphor & 1146 & 0.7 & 0.7 & 0.8 \\
4-terpineole & 1177 & 2.6 & 2.9 & 4.0 \\
$\alpha$-Terpineole & 1196 & - & - & 2.1 \\
Anethole & 1253 & 64.6 & 67.4 & 31.9 \\
Eugenol & 1359 & & - & 2.8 \\
$\alpha-($ E)-bergamotene & 1435 & 1.7 & 2.1 & 4.5 \\
a-humulene & 1455 & - & - & 0.9 \\
epi-alpha-Cadinol & 1640 & - & - & 15.1 \\
(Z)-Methyl jasmonate & 1649 & - & - & 2.0 \\
Octadeca-9,12,15-trienal & 2061 & - & - & 4.2 \\
Tetracontane & 2134 & 2.2 & 0.9 & - \\
10-demethylsqualene & 2212 & - & - & 4.5 \\
\hline SD = Steam distillation. & \multicolumn{5}{|c}{} \\
$\mathrm{MO}=$ Hydrodistillation using microwave oven. & \\
$\mathrm{SC}=$ Supercritical CO & &
\end{tabular}

\section{Experimental Section}

Plant material. Samples of leaves of three species were collected on April 2000 in the Francisco José de Abreu Matos Medicinal and Aromatic Plants Garden of the Federal University of Ceará (UFC) and promptly extracted by $\mathrm{SD}$ and $\mathrm{MO}$. The samples submitted to supercritical $\mathrm{CO}_{2}$ extraction were prior dried at room temperature. Vouchers specimens have been deposited in Prisco Bezerra Herbarium of the UFC under numbers 18.671, 29.315 and 27.020 respectively.

Oil extraction. Samples $(1 \mathrm{Kg})$ of fresh material were extracted by steam distillation (SD) during three hours and produced oils in 3.6\%, 2.5\% and $0.6 \%$ yields respectively for $O$. gratissimum, $O$. micranthum and $O$. selloi. Hydrodistillation using a modified microwave oven (MO) during $8 \mathrm{~min}$ in a device adapted for oil extraction ${ }^{10}$ produced $0.3 \%$ (O. gratissimum), $0.4 \%$ (O. micranthum) and $0.2 \%$ (O. selloi) yields and supercritical $\mathrm{CO}_{2}$ extraction (SC) at $32.9^{\circ} \mathrm{C}$ and $70 \mathrm{bar}$ for a $30 \mathrm{~min}$ contact and one hour of extraction, produced $0.1 \%, 0.2 \%$ and $2.1 \%$ for $O$. gratissimum, O. micranthum and $O$. selloi, respectively

Oil analysis. The oils obtained from leaves were analyzed in a Hewlett-Packard GC/MS model 5971A, under the following conditions: Column: Dimethylpolysiloxane DB-1 fused silica capillary column $(30 \mathrm{~m} \times 0.25 \mathrm{~mm}$, film thickness $0.1 \mu \mathrm{n})$; carrier gas: Helium $(1 \mathrm{~mL} / \mathrm{min})$; injector temperature: $250^{\circ} \mathrm{C}$; detector temperature: $200^{\circ} \mathrm{C}$; column temperature: from $35^{\circ}$ to $180^{\circ} \mathrm{C}$ at 
$4^{\circ} \mathrm{C} / \mathrm{min}$ then from $180^{\circ}$ to $250^{\circ} \mathrm{C}$ at $10^{\circ} \mathrm{C} / \mathrm{min}$; mass spectra: electronic impact $70 \mathrm{eV}$. Individual components were identified by spectrometric analyses using two computer libraries MS searches and retention indices as pre-selection aid ${ }^{11}$ as well as by visual mass spectra comparison with literature data for confirmation ${ }^{12,13}$.

\section{Conclusions}

The results led to the following conclusions: a) eugenol was present in the oils of the three species; b) eugenol was the major component extracted by the three methods in the essential oils obtained from O. gratissimum and O. micranthum; c) the relative concentration of anethole in $O$. selloi and eugenol in O. micranthum and O. gratissimum was lower by using supercritical $\mathrm{CO}_{2}$ extraction; f) the qualitative and quantitative variation in the composition of the essential oils demonstrated the importance of registering in the publications the extraction process and the oil yield values.

\section{Acknowledgements}

Authors are thankful to Dr Raymond Harley from the Kew Gardens Herbarium for species identification. Thanks are also due to the Brazilian government agencies for research development $\mathrm{CNPq}$ and FUNCAP-CE for financial support that made possible this research.

\section{References}

1. Silva, M. G. V.; Craveiro, A. A.; Matos, F. J. A.; Machado, M. I. L.; Alencar, J. W. Fitoterapia 1999, 70, 32.

2. Charles, D. J.; Simon, J. E.; Wood, K. V. J. Agric. Food Chem. 1990, 38, 120.

3. Maia, J. G.; Ramos, L. S.; Luz, A. I. R.; Silva, M. L.; Zoghbi, M. G. Flav. and Fragr. 1988, 177.

4. Silva, M. G. V.; Craveiro, A. A.; Matos, F. J. A.; Machado, M. I. L.; Alencar, J. W.; Aurélio, F. K. F. J. Essent. Oil Res. 1998, 10, 77.

5. Lino, C. S.; Silva, M. G. V.; Sousa, F. C. F.; Gomes, A. B.; Viana, G. S. B. In XVI Simp. Bras. de Plantas Med. do Brasil; 2000, 279.

6. Braga, R. Plantas do Nordeste Especialmente do Ceará; Mossoró: Brazil, 1976.

7. Freixa, B.; Vila, R.; Vargas, L.; Lozano, N.; Adzet, T.; Cañigueral, S. Phytotherapy Res. 1998, 12, 427.

8. Martins, E. R. In Plantas Medicinais, aromáticas e condimentares : avanços na Pesquisa agronômica, Ed. UNESP: Botucatu-SP, 1988, p 97. 
9. Moraes, 1.A.S.; Facanali, R.; Marques, M. O. M.; Ming, L.C.; Meireles, A. A.; Acad Bras Cienc. 2002, 74, 183.

10. Craveiro, A. A.; Matos, F. J. A.; Alencar, J. W.; Plumel, M. M. Flav. Fragr. J. 1989, 4, 43.

11. Stenhagen, E.; Abrahamson, S.; McLafferty, F.W. Registry of Mass Spectra Data; J. Wiley \& Sons: New York, 1974.

12. Craveiro, A. A.; Matos, F. J. A.; Alencar, J. W. J. Nat. Prod. 1984, 47, 890.

13. Adams, R.P. Identification of Essential Oil Components by Gas Chromatography/Quadrupole Mass Spectroscopy. Allured Publishing Corporation: Carol Stream, Illinois, USA, 2001. 